\title{
PIIISGUC.ORG
}

"iş, GÜÇ" ENDÜSTRI iLişKILERI VE INSAN KAYNAKLARI DERGISi

"IS, GUC" INDUSTRIAL RELATIONS AND HUMAN RESOURCES JOURNAL

\section{Effect of Loneliness at Work on the Employees' Intention to Leave}

\author{
Assist.Prof.Dr.Kurtuluş KAYMAZ \\ Uludag University \\ Assist.Prof.Dr.Umut EROĞLU \\ Çanakkale 18 Mart University \\ Assoc.Prof.Dr.Yücel SAYILAR \\ Uludag University
}

Ocak/January 2014, Cilt/Vol: 16, Sayı/Num: 1, Page: 38-53

ISSN: 1303-2860, DOI: 10.4026/1303-2860.2014.0241.x

Makalenin on-line kopyasına erişmek için / To reach the on-line copy of article:

http://www.isguc.org/?p=article\&id=535\&cilt=16\&sayi=1\&yil=2014

Makale İçin İletişim/Correspondence to:

Yard.Doç.Dr. Kurtuluş KAYMAZ/ Email: kurtuluskaymaz@uludag.edu.tr 


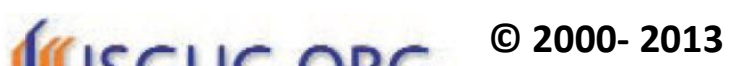 \\ "İş,Güç" Endüstri ilişkileri ve İnsan Kaynakları Dergisi "Işs,Güç" Industrial Relations and Human Resources Journal
}

\author{
Ocak/January 2014, Cilt/Vol: 16, Say1/Num: 1, \\ Sayfa/Page: 38-53, DOI: 10.4026/1303-2860.2014.0241.x
}

"İş,Güç" Endüstri İlişkileri ve İnsan Kaynakları Dergisi, yılda dört kez yayınlanan hakemli, bilimsel elektronik dergidir. Çalışma hayatına ilişkin makalelere yer verilen derginin temel amact; belirlenen alanda akademik gelişime ve paylaşıma katkıda bulunmaktır.

"İş,Güç" Endüstri İlişkileri ve İnsan Kaynakları Dergisi'nde, 'Türkçe' ve 'İngilizce' olarak iki dilde makale yayınlanmaktadır. "İş,Güç" Endüstri İlişkileri ve İnsan Kaynakları Dergisi, ulusal ve uluslararası birçok indekste taranmaktadır. (Cabell's Directories, Ebsco Socindex, Index Islamicus, Index Copernicus International, Worldwide Political Science Abstracts, Sociological Abstract, Ulakbim Sosyal Bilimler Veritabanı, ASOS Index)

Editörler Kurulu / Editorial Board Aşkın Keser (Uludă̆ University) K.Ahmet Sevimli (Uludăg University) Şenol Baştürk (Uludağ University)

\section{Editör / Editor in Chief}

Şenol Baştürk (Uludăg University)

\section{Uygulama / Design}

Yusuf Budak (Kocaeli University)

Tarandığı Indeksler / Indexes ASOS INDEX

CABELL'S DIRECTORIES EBSCO SOCINDEX Index ISLAMICUS Index COPERNICUS Int. Sociological Abstract ULAKBİM Sosyal Bilimler Veritanı

Worldwide Political Science Abstracts

\author{
Yayın Kurulu / Editorial Board \\ Dr.Şenol Baştürk (Uludă̆ University) \\ Yrd.Doç.Dr.Zerrin Fırat (Uludă̆ University) \\ Doç.Dr.Aşkın Keser (Uludă̆ University) \\ Prof.Dr.Ahmet Selamoğlu (Kocaeli University) \\ Yrd.Doç.Dr.Ahmet Sevimli (Uludağ University) \\ Doç.Dr.Abdulkadir Şenkal (Kocaeli University) \\ Doç.Dr.Gözde Yılmaz (Marmara University) \\ Yrd.Doç.Dr.Memet Zencirkıran (Uludă̆ University)
}

Uluslararası Danışma Kurulu / International Advisory Board

Prof.Dr.Ronald Burke (York University - Kanada)

Assoc.Prof.Dr.Glenn Dawes (James Cook University - Avustralya)

Prof.Dr.Jan Dul (Erasmus University - Hollanda)

Prof.Dr.Alev Efendioğlu (University of San Francisco - ABD)

Prof.Dr.Adrian Furnham (University College London - Ingiltere)

Prof.Dr.Alan Geare (University of Otago - Yeni Zellanda)

Assoc. Prof. Dr. Diana Lipinskiene (Kaunos University - Litvanya)

Prof.Dr.George Manning (Northern Kentucky University - ABD)

Prof.Dr.Mustafa Özbilgin (Brunel University - UK)

Assoc. Prof. Owen Stanley (James Cook University - Avustralya)

Prof.Dr.Işık Urla Zeytinoğlu (McMaster University - Kanada)

Ulusal Danışma Kurulu / National Advisory Board

Prof.Dr.Yusuf Alper (Uludă̆ University)

Prof.Dr.Veysel Bozkurt (Ístanbul University)

Prof.Dr.Toker Dereli (Işık University)

Prof.Dr.Nihat Erdoğmuş (İstanbul Şehir University)

Prof.Dr.Ahmet Makal (Ankara University)

Prof.Dr.Süleyman Özdemir (İstanbul University)

Prof.Dr.Ahmet Selamoğlu (Kocaeli University)

Prof.Dr.Nadir Suğur (Anadolu University)

Prof.Dr.Nursel Telman (Maltepe University)

Prof.Dr.Cavide Uyargil (Istanbul University)

Prof.Dr.Engin Yildırım (Anayasa Mahkemesi)

Doç.Dr.Arzu Wasti (Sabancı University)

Dergide yayınlanan yazılardaki görüşler ve bu konudaki sorumluluk yazarlarına aittir.

Yayınlanan eserlerde yer alan tüm içerik kaynak gösterilmeden kullanılamaz.

All the opinions written in articles are under responsibilities of the authors.

The published contents in the articles cannot be used without being cited. 


\title{
Effect of Loneliness at Work on the Employees' Intention to Leave
}

\author{
Assist.Prof.Dr.Kurtuluş KAYMAZ \\ Uludag University \\ Assist.Prof.Dr.Umut EROĞLU \\ Çanakkale 18 Mart University \\ Assoc.Prof.Dr.Yücel SAYILAR \\ Uludag University
}

\begin{abstract}
As loneliness and loneliness at work are important socio-psychological concepts that affect employee job performance, they should be carefully considered with respect to human-oriented corporate practices. Loneliness at work may decrease organizational commitment and weaken social relationships, thereby adversely affecting the employee's level of productivity. Loneliness at work may further result in intention to leave and perhaps even culminate in actual leaving behavior. Therefore, "loneliness at work" is an important phenomenon that should be carefully addressed in terms of human resources practices. The development of social relationships between employees both at work and outside of work, the improvement of formal relations between senior and junior employees, team collaboration, the activation of formal and informal communication channels, and the employment of experts providing psychological / social support services are organizational measures that will help to reduce loneliness at work. The aim of the research is to determine the effect of loneliness at work on the employee's intention to leave. In the study, two main survey were used from the related literature for both loneliness at work and intention to leave in order to collect data. A primary components analysis (PCA) was employed to create the loneliness index, and the calculated index values were included in the regression analysis as explanatory variables. The results indicate that in the context of this study loneliness at work effect the employee's intention to leave. On the other hand, employees included in the research do not feel lonely at their workplaces.
\end{abstract}

Key Words: Loneliness, loneliness at work, intention to leave, organizational commitment, employee satisfaction.

\section{Özet}

Yalnızlık ve işyerinde yalnızlık, çalışanların sosyo-psikolojik açıdan çalışma performanslarını etkileyen ve "insan" odaklı kurumsal uygulamalar açısından dikkatle değerlendirilmesi gereken önemli kavramlardır. Issyerinde yalnızlık hissi, kurumsal bağlllı̆̆ azaltabilmekte, sosyal ilişkileri zayıflatabilmekte ve dolaylstyla işgücü verimliliğini negatif yönde tetikleyebilmektedir. Bu durum göreli olmakla birlikte işten ayrlma niyetinin oluşmasına ve belki de bir sonraki adımda fiili işten ayrllma davranışının ortaya çıkmasına zemin hazırlayabilmektedir. Bu çerçevede, araştırmadan elde edilen en önemli bulgu, işyerinde yalnızlık hissinin, işten ayrılma niyeti oluşturduğu yönündedir. Dolayısıyla insan kaynakları pratikleri açısından "işyerinde yalnızlık", üzerinde dikkatle durulması gereken önemli bir olgudur. Çalışanlar arası iş içi ve iş dlşı sosyal ilişkilerin gelişstirilmesi, formel düzeyde ast üst iliş̧kilerinin iyileş̧tirilmesi, takım çalışmaları, biçimsel ve biçimsel olmayan iletişim kanallarının etkinleş̧tirilmesi, psikolojik / sosyal destek hizmeti sunan uzmanların istihdamı vb. uygulamalar, işyerinde yalnızlık hissini azaltan örgütsel önlemler olarak düşünülebilmektedir. Bu araştırmanın amacı, işyerinde yalnızlık hissinin çalışanların işten ayrıla niyeti üzerindeki etkilerini tespit etmektir. Araştırma verilerinin toplanabilmesi için ilgili literatürde yer alan ve işyerinde yalnızlık ile işten ayrılma niyetini ölçümlemeye yarayan iki ayrı ölçek kullanılmıştır. Issyerinde yalnızlık endeksinin oluşturulması için PCA analizi kullanılmış, hesaplanan endeks değerleri regresyon analizine açıklayıcı değişkenler olarak dahil edilmiştir. Elde edilen sonuçlar, bu araştırma kapsamında iş̧yerinde yalnızlı̆̆ın, iş̧ten ayrllma niyeti üzerinde etkisi olduğunu ortaya koymaktadır. Diğer taraftan, araştırmaya katılan çalışanların işyerinde yalnız hissetmedikleri bulgulanmıştır.

Anahtar Kelimeler: Yalnızlık, işyerinde yalnızlık, işten ayrılma niyeti, örgütsel bağlllık, çalışan memnuniyeti. 
"iş, GÜç" Endüstri İlişkileri ve İnsan Kaynakları Dergisi

"IS, GUC" Industrial Relations and Human Resources Journal
Ocak/January 2014 - Cilt/Vol: 16 - Sayı/Num: 01

Sayfa/Page: 38-53, DOI: 10.4026/1303-2860.2014.0241.x

\section{Introduction}

This study aims to reveal the effect of loneliness at work on the intention to leave the organization. Compared to the foreign literature, the Turkish literature contains a limited number of scientific studies on the effects of loneliness and loneliness at work. Demir's (1989) study, which tests the validity and reliability of the UCLA loneliness scale; Yilmaz's (2008) study, which addresses organizational commitment and life satisfaction; the study of Dogan et al. (2009), which developed the Turkish form of loneliness at work scale; and the study of Erdil \& Tosun (2011-2012), which examines the relationship between organizational commitment and loneliness at work.

The emphasis on the "social human being" in the Hawthorne study forms the first concrete scientific evidence of the fact that employees at work are, as "human beings", in need of "relationships". In this sense, the "professional life" presented by organizations to their employees and the accompanying collective life indicate that individuals cannot be alone, even when at work.

While the efforts to create a social environment in organizations hinder the initiatives to improve technical conditions, enhancement of the social interactions among employees pave the way for the emergence of individual skills at the team or group level. In organizations, individual-based actions lead to collective capabilities. In addition, social activities are organized to support the working performance of employees, and organizational practices are developed to ensure that employees have good relationships as human beings. Ultimately, efforts are made to create social people acting collectively in solidarity rather than people performing on their own. Acting collectively in solidarity can be considered a factor that prevents isolation at work.

\section{Literature Review}

\subsection{Loneliness and Loneliness at Work}

Loneliness is an important parameter in analyzing social interactions and interpersonal relationships. Loneliness often refers to an undesired situation and is an issue to be addressed at the individual level (Forbes, 1996: 352; Booth, 1983: 116). Erns and Cacioppo (1999) define loneliness as a weakness experienced in interpersonal relationships and in the ability to socialize. Peplau (1955: 1476) describes loneliness as an unfavorable situation, an individual characteristic and a state of weakness that is not recognized. Loneliness is a phenomenon with a psychological aspect and is perceived as a state of incapability in social dialogues differently from the state desired by the individual (Ponzetti, 1990: 336; Nurmi \& Salmela-Aro, 1997: 205; Savikko et al., 2005: 224). Especially, the isolation that may occur in childhood where weak friendship relations exist (Asher \& Paguette, 2003: 77; Peplau, 1955: 1476) may lead to significant adaptation problems in future periods of the individual's life (Asher et al., 1984: 1456). Loneliness is more frequently observed in adolescents and young adults (Nurmi \& Salmela-Aro, 1997: 205; Lasgaard, 2007: 1359). In a study of elderly people in Finland, Savikko and colleagues (2005) found that $5 \%$ of the elderly people, a group that constituted $39 \%$ of the population, felt lonely. The study further states that elderly people who live in rural areas, are of a low social status, generate a low level of income and are widowed experience greater loneliness than those who do not experience such conditions. At the individual level, the most prominent personal reasons for loneliness include disease, fear of death, physical weakness and the absence of friends.

Cognitive theory forms the basic theoretical framework of studies on loneliness. Accordingly, cognitive theory focuses on the individual's social ties and relationships and on the perceptions of the individuals regarding loneliness. Cognitive theory expresses that loneliness arises as a consequence of the discrepancy between the desired social relationships and the actual social interactions. Further, past experiences of the individual and his/her social interactions with other people are the determining factors in loneliness (Peplau \& Perlman, 1984: 14). 
The phenomenon of loneliness is analyzed based on three fundamental assumptions in the literature (Kraus et al., 1993: 37). The first assumption is that loneliness arises as a consequence of the social lifestyle of the individual and is considered as a state of perceived incapability. The second assumption suggests that loneliness is a subjective feeling that is directly related to the individual and the individual's experiences. The third assumption is that loneliness describes a state that is unpleasant and distressing. These three assumptions constitute the starting point of the scientific studies on loneliness.

Two types of loneliness are mentioned in the relevant literature (Ernst and Cacioppo, 1999: 5): the first is emotional loneliness, and the second is social loneliness. Although correlations between the two types of loneliness cannot be clearly established, it is commonly agreed that both types of loneliness are based on "relationships". Emotional loneliness is evident in one-to-one relationships with individuals, whereas social loneliness occurs in the presence of relations with more than one person or with groups. Within the scope of these two concepts, loneliness at the emotional level is considered as a state of being self-enclosed, whereas loneliness at the social level is based on a deficiency in the relationships with people within the social network, such as friends, peers, colleagues or neighbors.

As loneliness may occur in different forms (Lopata, 1969: 250-251), it is not necessarily an emotion felt only when one is alone. A feeling of loneliness may occur when a) one loses a loved one (due to death, etc.); b) one has no one with whom to share emotions, ideas, values, etc.; c) one's family, friends or social circle are uncaring or loveless; or d) with respect to one's work environment, one has no one with whom to share the workload and work with in solidarity.

It is reported that individuals who feel lonely in a "social environment" experience loneliness more profoundly than those who feel lonely when by themselves (Wright et al.,
2006: 59). Lopata, (1969: 249) stated that loneliness is a type of emotion felt more heavily when relations with other people completely cease, are interrupted or are damaged. In this context, loneliness is a multivariate phenomenon that characterizes an unpleasant, painful and anxious state (Ponzetti, 1990: 336; Mellor et al., 2008: 214).

Loneliness, however, does not arise only as a pathological case. Rather, loneliness depicts a normative state and is an emotion that may be felt at various times in life by people of any age group (Ponzetti, 1990: 336). On the other hand, unlike other forms of loneliness, chronic loneliness is shaped by the impact of factors such as depression, alcohol addiction or serious health problems, such loneliness is related to the inner world of the individual and is therefore affected by his/her lifestyle (Asher \& Paguette, 2003: 75).

There are numerous variables determining why one feels lonely. In Ponzetti (1990)'s study of college students, it is emphasized that personal characteristics of the individual as well as his/her interpersonal relationships and his/her way of positioning himself/herself in the social network are basic variables triggering the phenomenon of loneliness. Accordingly, Ponzetti suggests that individuals feeling lonely describe themselves as shy (Erenst \& Cacioppo, 1999: 6) or depressed. It is also reported that individuals feeling lonely have a low level of self-esteem and exhibit symptoms such as despair and drowsiness while also feeling unloved. It is reported that individuals who suffer feelings of loneliness are more pessimistic than others and ascribe generally more negative meanings to incidents around them. This abnormality in attitudes and behaviors as a consequence of the feeling of loneliness constitutes an impediment, with respect to motivation, to the successful conduct of interpersonal relationships (Revenson, 1981: 568).

Similarly, Kraus and colleagues (1993) indicate that there are various individual and social factors affecting feelings of loneliness. In this framework, rarely experienced social interactions, a low number of friends, failure to 
participate in social networks or infrequent participation in social networks are considered important "social" indicators of loneliness. Furthermore, a low level of selfesteem (Lasgaard, 2007: 1359), a nonextroverted personality type, a high level of shame, high social-based anxieties, neuroticism or external locus of control (Nurmi \& Salmela-Aro, 1997: 205) are acknowledged to be prominent indicators that suggest an individual is experiencing feelings of loneliness. Booth (1983) notes that individuals who feel lonely have external locus of control, live under the influence of the past and the influence of unpleasant past experiences, are depressive and have unrealistic expectations.

It is also known that individuals who experience loneliness have anatomical health problems. In this context, it is reported that lonely people are less healthy compared to others, that clearer results are obtained in medical treatments of people who are not identified as lonely, and that individuals who feel lonely are exposed to more stress than others and are therefore more open to cardiologic problems (Cacioppo et al., 2003: 7173).

With respect to interpersonal relationships, individuals who experience loneliness are reported to spend most of their time by themselves and have difficulty making friends. It is also noted that they speak less and do not exhibit warm and sincere behaviors when communicating with others. Accordingly, it is noted that individuals who feel lonely have a limited social network (Ponzetti, 1990: 337).

Loneliness at work is described as a situation that arises from poor interpersonal relations at the workplace and one that creates distress (Wright et al., 2006: 60). Psychologicalbased factors such as loneliness at work may adversely affect relations with other employees and negatively impact working performance and organizational commitment (Yilmaz, 2008: 1087). Loneliness, when decided to leave the workplace, is a manifestation of a negative organizational climate (Wright et al, 2006: 59).
Loneliness at work and social isolation are often confused with each other. Social isolation means the "complete" cessation of communication with society and with one's close social environment (friends, family, etc.) along with the avoidance of making contact with others. Social isolation results in the emergence of emotional and/or psychological disorders in the individual. Anger, sadness and anxiety are among the significant symptoms of social isolation. However, loneliness at work suggests some problems with social interactions without any definite interruption of the social environment. An individual who feels lonely at work does not break off his/her communication with the social environment. On the contrary, this individual shows a willingness to engage in interactions with people and requests social support from his/her colleagues, managers and junior employees. Accordingly, loneliness is an early symptom indicating that the individual may be forced into social isolation (Cacioppo \& Patrick, 2008: 58).

It is reported that individuals who feel lonely have more prejudices and negative perceptions regarding their relationships with their friends compared to those who do not experience feelings of loneliness (Erenst \& Cacioppo, 1999: 6). From this perspective, one might assume that employees who experience loneliness at work may have prejudices regarding their relationships with their colleagues.

The research conducted by Erdil and Ertosun (2011: 520) regarding loneliness at work puts forth the idea that loneliness unfavorably impacts the social and professional life of the employee. Their study analyzes the effects of the relation between loneliness and social climate on the welfare of employees, and the results indicate that a social climate promoting the development of positive relationships in organizations reduces the loneliness of employees. Within this context, the study emphasizes that the social climate has a primary and determinative role in the feeling of loneliness at work. 
Loneliness is one of the significant determinants of life satisfaction, and as such, it may adversely affect quality of life (Savikko et al., 2005: 224). Civitci and Civitci (2009: 957) attempt to reveal the relation between loneliness and life satisfaction, which is defined as the entire cognitive assessment of an individual with respect to his/her life. According to the findings of the study, as loneliness decreases, overall life satisfaction increases. The same study also suggests that positive judgments and assessments of the individual regarding his/her life may help him/her easily develop more effective and more satisfactory relationships that will ensure that the individual feels less lonely. Another study notes that loneliness negatively affects life satisfaction (Mellor et al., 2008: 214). In a study of adolescents, Neto (1992) find that social concerns and social acceptance by society are important determinants of loneliness. This study also notes that individuals who have low social anxiety and receive high social acceptance have decreased feelings of loneliness.

\subsection{Loneliness at Work and Intention to}

Leave

When considered at the organizational and individual level, employee turnover is an important human resource problem. In organizational terms, an increase in employee turnover means a loss of qualified labor, an increase in costs incurred for investments in relevant personnel training (Liu et al., 2010: 617). On the other hand, personnel replacement has positive results with respect to the transfer of new knowledge, skills and capabilities to the company and the introduction and impact of new ideas, new people and positive changes (Mobley, 1982a: 121).

While examining the literature relating to employee turnover, the conceptual study of Bluedorn (1982) has a guiding quality. Bluedorn studies the concept of employee turnover by dividing it into two behaviors: intention to leave and actual leaving. In his study, Bluedorn emphasizes that there exists a significant and positive relationship between the intention to leave and actual leaving behavior. Accordingly, it is noted that the intention to leave is the strongest early symptom of the actual leaving behavior (Plooy \& Roodt, 2010: 3).

Intention to leave is used to express the possibility and subjective prediction that the individual will soon leave the organization. In this framework, intention to leave describes the desire of the employee to quit the organization in the near future in a conscious and planned manner (Mobley et al., 1978: 409). It is known that numerous variables play a role in the formation of the intention to leave. Accordingly, it is possible for an individual to have the intention to leave depending on various factors, such as the reduction in the level of support received from the organization or the organization's managers (Ozdevecioglu, 2004: 103), low wages (Cho et al., 2009: 376; Rosser, 2004: 293), the individual's dissatisfaction with the job, a low level of motivation experienced by the employee, a high level of stress experienced in the workplace, poor working conditions, disconnectedness that the individual experiences in social relations, more attractive job opportunities outside the organization, poor career opportunities within the existing organization, in-house conflicts and injustices occurring within the organization.

Simon and colleagues (2009) categorize the factors affecting the employee's intention to leave under six main headings. Accordingly, the following factors may have an effect on the employee's intention to leave: a) individual factors (age, gender, marital status, conflict between job and family, long working hours, etc.); b) health factors (emotional burnout, physical incapability, etc.); c) social environment factors at the workplace (conflicts with senior management, poor relations with colleagues, etc.); d) factors relating to the quality of the work (insufficient physical and emotional conditions at work); e) organizational factors (role conflict, adaptation problems, limited career and development opportunities, etc.); and f) labor market factors (opportunities for jobs with higher wages in the market, better career opportunities in other 
firms, etc.). Within this context, failure to meet emotional expectations and insufficient social dialogues within the workplace lead the individual to experience feelings of loneliness that may result in the individual's intention to leave.

Particularly, a negative correlation is observed between organization commitment and intention to leave (Labatmediene et al., 2007: 206; Karadag et al., 2011: 163). Accordingly, higher organizational commitment results in reduced levels of intention to leave. This finding confirms the negative correlation between organization commitment and intention to leave the organization by Allen and Meyer (1990). It can be concluded that loneliness may negatively affect commitment to the organization, which in turn, may have an effect on intention to leave (Ertosun \& Erdil, 2012: 474).

Stress at work plays an exceptionally huge role in the individual employee's intention to leave. Emotional burnout that results from stress at work affects the employee's voluntary decision to leave (Pidd \& Roche, 2009: 219). Given that loneliness at work leads to stress (Cacioppo et al., 2003: 72; Liu \& Guo, 2007: 1276), it would not be wrong to think that loneliness initially gives rise to stress, which in turn, leads to the intention to leave.

Loneliness is an important factors in job satisfaction. It is observed that a negative correlation exists between job satisfaction and intention to leave. That is, employees with high job satisfaction have a low level of intention to leave (Liu et al., 2010: 617, Dhar \& Dhar, 2010: 562; Tak \& Ciftcioglu, 2009: 173). Thus, it can be concluded that loneliness negatively affects job satisfaction and that an employee with reduced job satisfaction is more likely to experience intention to leave.

In the literature, numerous studies relate intention to leave to various factors, such as organizational commitment, job satisfaction, stress (Pidd \& Roche, 2009: 219; Dhar \& Dhar, 2010: 562), workplace climate (Hwang \& Chang, 2009: 74), organizational citizenship (Tsai \& Wu, 2010: 3566), organizational justice (Loi et al., 2006: 105), and quality of life (Huang et al, 2007: 738). Nevertheless, when related literature is examined, only a limited number of academic studies establish a direct link between intention to leave and loneliness at work. Therefore, this study aims to contribute to the academic efforts in the stated area, particularly with respect to Turkish literature.

This study seeks answers to two basic questions: i) Do the employees in the production facilities where the research is being conducted feel lonely? And ii) Does loneliness at work play any role in the employee's intention to leave? In this framework, the study aims to test the following hypotheses:

Hypothesis 1: Employees experience loneliness in the workplace.

Hypothesis 2: Loneliness at work affects the employee's intention to leave.

\section{Method}

\subsection{Participants}

The research was conducted using a sample group of 237 participants. Preinterviews were conducted with human resource managers of the companies to decide whether the questions relating to the measurement of the "intention to leave" would create concerns with respect to the terms of employment. Furthermore, all items for the measurement of loneliness at work and intention to leave were reviewed with human resources managers, and any items that might lead to misunderstanding by the employees were revised.

As this study basically aims to reveal the effect of loneliness at work on intention to leave, the employee's intention to leave is also estimated by examining the frequency of their job changes throughout their careers. Although more than one variable affects the decision of the individual to change his/her job, it is assumed that individuals who more frequently change their jobs have a higher level of intention to leave than those who do not frequently change jobs. 
The sample group included in the research was assessed on the basis of demographic position, gender, tenure, education, age and turnover frequency (Table 1).

Table 1: Study participants' profile

\begin{tabular}{|c|c|c|c|c|c|c|}
\hline Position \% & & & & & & \\
\hline Manager & 10.5 & & & & & \\
\hline Office Personnel & 20.7 & & & & & \\
\hline Blue Collar & 68.8 & & & & & \\
\hline \multicolumn{7}{|l|}{ Gender $\%$} \\
\hline Female & & 24.5 & & & & \\
\hline Male & & 75.5 & & & & \\
\hline \multicolumn{7}{|l|}{ Tenure $\%$} \\
\hline Up to 5 years & & & 45.1 & & & \\
\hline 6-10 yrs & & & 30,7 & & & \\
\hline $11-15 \mathrm{yrs}$ & & & 17.8 & & & \\
\hline $16-20 \mathrm{yrs}$ & & & 4.3 & & & \\
\hline 21 yrs and more & & & 2.1 & & & \\
\hline \multicolumn{7}{|l|}{ Education $\%$} \\
\hline General Education & & & & 61.2 & & \\
\hline Vocational Education & & & & 17.7 & & \\
\hline Graduate and Post Graduate & & & & 21.1 & & \\
\hline \multicolumn{7}{|l|}{ Age $\%$} \\
\hline Up to 20 years & & & & & 2.1 & \\
\hline $21-30$ yrs & & & & & 36.2 & \\
\hline $31-40 \mathrm{yrs}$ & & & & & 46.1 & \\
\hline $41-50 \mathrm{yrs}$ & & & & & 15.1 & \\
\hline 51 yrs and more & & & & & 0.5 & \\
\hline \multicolumn{7}{|l|}{ Turnover Frequency \% } \\
\hline First work place & & & & & & 11 \\
\hline Second work place & & & & & & 32.5 \\
\hline Third work place & & & & & & 35.9 \\
\hline Fourth work place & & & & & & 11.4 \\
\hline Fifth work place & & & & & & 3.4 \\
\hline Sixth work place & & & & & & 5.8 \\
\hline
\end{tabular}

\subsection{Measures}

In the relevant literature, two different scales are used to measure loneliness and loneliness at work. The concept of loneliness is measured through the UCLA loneliness scale first developed by Russell and Peplau in 1978. The scale was then revised by the same researchers in 1980 and finalized (Version 3) by Russell in 1996.

The loneliness at work scale, which consists of two factors, was developed by Wright, Burt and Strongman (2006). The first factor measures "emotional deprivation" and is composed of 9 items. The second factor assesses "social companionship" and is composed of 7 items. This scale, developed by Wright and colleagues, was introduced into the Turkish literature by Dogan, Çetin and Sungur in 2009. With respect to the Turkish version of the loneliness at work scale, explanatory and confirmatory factor analysis was performed. For the entire scale, Cronbach's alpha value was 0.91, the emotional deprivation factor was 0.87 and the social companionship factor was 0.83 . In this study, the Turkish version of the loneliness at 
work scale was used. For the measurement of the employee's intention to leave, 2 items from Mobley's study (1982b) were included in the research.

The first part of the scale gathers the demographic information (age, seniority, education, gender, position, turnover frequency) of the participants. The second part of the scale consists of items relating to loneliness at work, and the third part consists of items relating to intention to leave. A 5point Likert scale (Strongly Disagree $=1$ to Strongly Agree=5) was used in the study.

\section{Results}

The main objective of this research is to measure the possible effects of loneliness at work on the employee's intention to leave. Regression analysis was conducted to determine the effect. In the regression analysis, "A Loneliness Index-LIND" was initially formed based on the loneliness at work scale. A primary components analysis (PCA) was employed to create the loneliness index, and the calculated index values were included in the regression analysis as explanatory variables. The primary reason a PCA is employed is because it helps to find the appropriate weights in the calculation of the loneliness index depending on the indicators used in the loneliness at work scale. The index values based on the determination of weights enable the regression analysis to produce more reliable results.

A PCA is a multivariate statistical analysis used to convert a multivariate data set into a consecutive orthogonal set of components that can explain the variance to as great a degree as possible. The PCA is also employed for indices in many diverse areas. The PCA aims to obtain a lesser number of independent linear combinations among a group of variables. That is, it aims to attain $k$ number of uncorrelated factors among $p$ number of original variables. In this context, the objective of the PCA may be said to be stinginess (Dunteman, 1989).

A PCA is applied taking into account the covariance matrix of the data matrix or correlation matrix of the standardized data matrix. If the variances of the variables are different from each other or the measurement units vary, the data matrix must be standardized (Johnson, 1998).

A PCA performs the following conversion:

$$
Y=X a
$$

where $p$ denotes the number of variables, $n$ the number of observations, $Y$ the primary component matrix, $a$ the optimal weight vector and $X$ the standardized data matrix. For instance, for $p=3$, the variance of $Y$ is:

$$
\operatorname{var}(Y)=\operatorname{var}\left(a_{1} X_{1}+a_{2} X_{2}+a_{3} X_{3}\right)
$$

or

$$
\operatorname{var}(Y)=\operatorname{var}\left(a_{1}^{2} s_{11}+a_{2}^{2} s_{22}+a_{3}^{2} s_{33}+2 a_{1} a_{2} s_{12}+2 a_{1} a_{3} s_{13}+2 a_{2} a_{3} s_{23}\right)
$$

where $S_{i j}$ denotes the covariance between $X_{i}$ and $X_{j}$. Equation (3) can be rewritten as:

$$
\operatorname{var}(Y)=a^{\prime} S a
$$

where $S$ is the variance-covariance matrix of the data matrix $X$.

The first primary component maximizes $\operatorname{var}(Y)=a^{\prime} S a$ under the normalization restriction of $a^{\prime} a=1$. Employing the lagrange multipliers technique, this process can be rewritten as follows:

$$
L=a^{\prime} S a-\lambda\left(1-a^{\prime} a\right)
$$

Accordingly, the first degree condition is estimated to determine $a$ : 


$$
\frac{\partial L}{\partial a}=\frac{\partial\left[a^{\prime} S a-\lambda\left(1-a^{\prime} a\right)\right]}{\partial a}=0
$$

The first degree condition is $2(S a-\lambda a)=0$ or $(S-\lambda I) a=0$ where $I$ is a unit matrix. The multiplier can be interpreted as a characteristic root of $S$ variance-covariance matrix, and the solution of the equation $(S-\lambda I) a=0$ corresponds to the characteristic vector $a$. Therefore, roots are obtained from the equation $|S-\lambda I|=0$. While there is undoubtedly more than one variable, here the highest root is sought. If $(S-\lambda I) a=0$ is multiplied by $a^{\prime}$, the following equation is obtained:

$$
a^{\prime} S a-a^{\prime} \lambda I a=0
$$

where $a^{\prime} a=1$ is a normalization and $\lambda$ is a scalar; thus, equation (7) becomes

$$
a^{\prime} S a=\lambda=\operatorname{var}(Y)
$$

where maximizing $\operatorname{var}(Y)$ results in the highest characteristic root.

By repeating this procedure and using the characteristic vectors $\lambda_{i}(i=1,2, \ldots, p)$, it is possible to obtain the primary components up to the $p^{\text {th }}$ primary component. Here, the values of the characteristic roots are ordered from the largest to the smallest (Jolliffe, 2002). Accordingly, the explained variance ratio obtained from the $i^{\text {th }}$ component is as follows:

$$
\delta_{i}=\frac{\lambda_{i}}{\lambda_{1}+\lambda_{2}+\ldots+\lambda_{p}},(i=1,2, \ldots, p)
$$

To form an index with primary component values, one must first select the important primary components. The second step requires weighting a $k$ number of primary components in such a manner that the sum of their variance explanation ratios is equal to one. Then, weighted primary components are used in the index calculation:

$$
\text { ind }_{s c r}=\sum_{i=1}^{k}\left[\frac{\delta_{i}}{\sum_{i=1}^{k} \delta_{i}} Y_{i}\right]
$$

where $e n d_{s k r}$ denotes index scores. Using the index scores, financial development indices for the provinces can be calculated as follows:

$$
\text { ind }=\frac{\left[\text { ind }_{s c r}-\text { mean }\left(\text { ind }_{s c r}\right)\right]}{\left.\left[\sum \mid \text { ind }_{s c r}-\text { mean }\left(\text { ind }_{s c r}\right)\right]\right] / n}+100
$$

Here, the mean of the index scores is zero (Atabek, 2005).

Figure 1 illustrates the LIND calculations for the participants depending on PCA. Generally, for the upper values of LND greater than 100, it can be said that participants experience feelings of loneliness. On the other hand, lower values indicate that participants do not feel lonely. Figure 1 clearly shows that most of the participants in this research do not experience feelings of loneliness. (Hypothesis 1 is not confirmed.) 


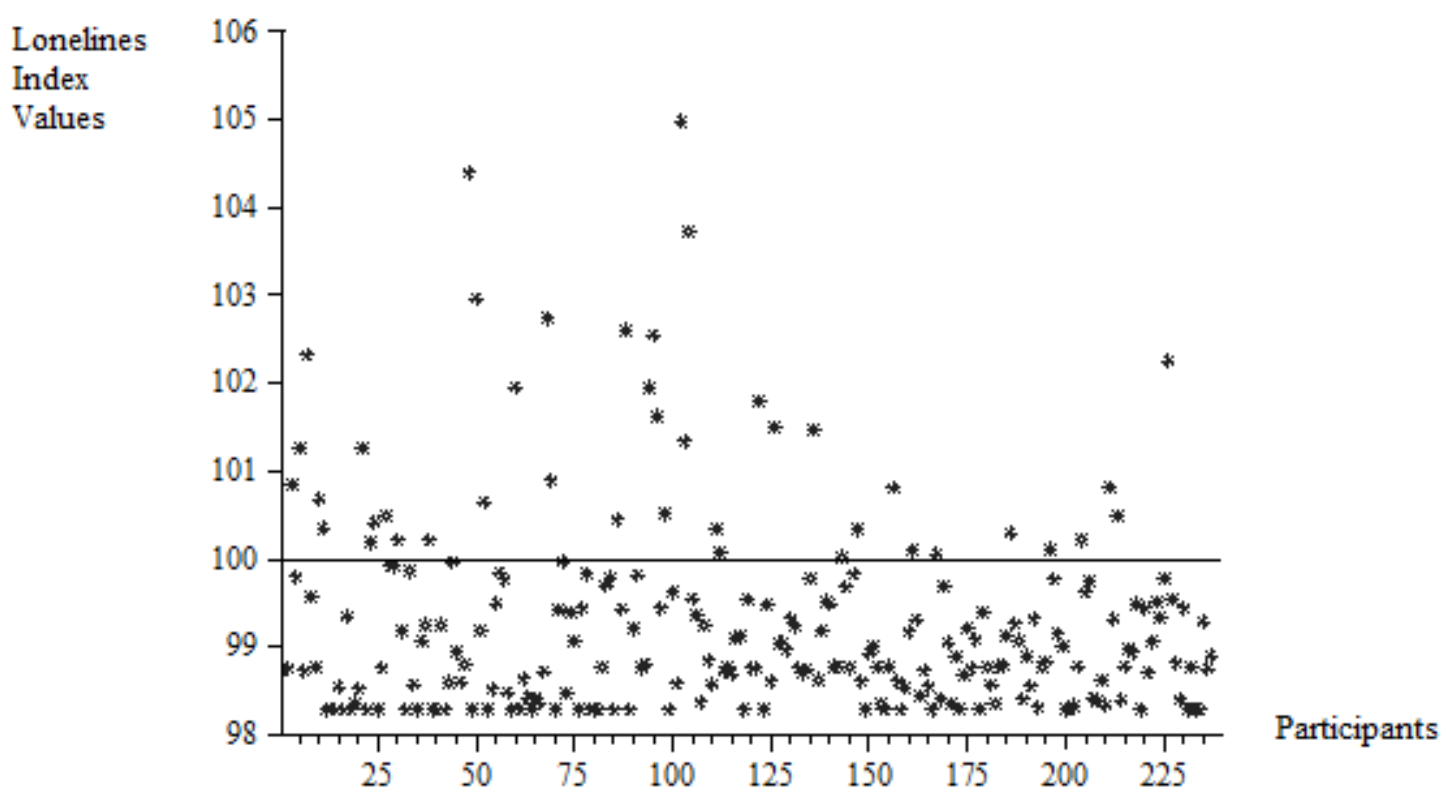

Figure 1: LIND Calculations

After introducing the loneliness index, the relationship between loneliness at work and intention to leave can be estimated by using regression analysis. Before proceeding with the regression analysis, however, it is necessary to examine the sample properties of the variables. Table 1 presents some descriptive statistics for the variables.

Table 1: Descriptive Statistics and Correlations for Variables

\begin{tabular}{lcccc}
\hline Variable & Mean & Max. & Min. & Std. Dev. \\
\hline LIND & 99.29 & 104.98 & 98.29 & 1.14 \\
$I N T L_{i}$ & 3.66 & 5.00 & 1.00 & 0.99 \\
\hline
\end{tabular}


Table 2: Regression Analysis Results

\begin{tabular}{ll}
\hline Dependent Variable: $I N T L_{i}$ & \\
\hline Constant & 17.80 \\
& $(0.00)^{*}$ \\
& \\
LIND & 0.14 \\
& $(0.01)$ \\
\hline$R^{2}$ & \\
Log likelihood & 0.026 \\
Heteroskedasticity Test: White & -327.99 \\
\end{tabular}

* Marginal significant levels are in parentheses.

Table 2 indicates that loneliness at work has a positive significant effect on intention to leave, with a unit increase in the loneliness index resulting in a 0.14 unit increase in intention to leave (Hypothesis 2 is confirmed.) Additionally, according to the White heteroskedasticity test results, there is no heteroskedasticity problem, and we can say that the standard errors are reliable.

Finally, we analyze the possible impacts of the intermediate variables of age, seniority and education in measuring the effects of loneliness at work on intention to leave. As the results show that the intermediate variables are statistically insignificant, the intermediate variables of age, seniority and education are excluded from the study.

\section{Conclusions}

This study primarily seeks answers to two questions: i) "Does loneliness at work have any effect on an employee's intention to leave?" and ii) "Do the employees working in organizations experience feelings of loneliness?" The most important finding of the study is that loneliness at work does have an effect on an employee's intention to leave. Considering that loneliness has negative implications that can be assessed at the individual, social and organizational levels, loneliness may result in the individual diverge from the organization. In this framework, the results of this research support the statements in the relevant literature (Pidd \& Roche, 2009; Cacioppo et al., 2003; Liu \& Guo, 2007; Labatmediene, Endriulaitiene \& Gustainiene, 2007; Loi et al., 2006; Peplau \& Perlman, 1984) that suggest loneliness may lead to stress, weak organizational commitment and problems in social relations, which in turn, may trigger the desire to leave the organization.

To address employee loneliness within organizations, some precautions must be taken at the organizational level. In this framework, the most critical factor is to enhance the level of organizational commitment; however, to increase the level of organizational commitment, employee satisfaction must be ensured. As the level of satisfaction among employees in the organization increases, the level of employee loneliness decreases, and as a consequence, organizational commitment increases and intention to leave decreases. There are a significant number of scientific studies in the literature that reveal the chain effect. On the other hand, the employees included in this study demonstrated a low level of job mobility (the percentage of those who changed jobs up to three workplaces was $79.4 \%)$. A low level of job mobility indicates that the employees, for the most part, intend to remain with the organization. 
Additionally, it was found that the individuals in the sample did not feel lonely in their work environment. This finding can be interpreted in various ways. In social terms, the Turkish society generally exhibits a collectivist social structure. This collectivist cultural structure directly affects the behaviors of individuals in both their social and their organizational lives. As a result of collectivist cultures, the motives to act together, to form strong social ties, to engage in collective behaviors against difficult conditions, and to adhere to the accompanying relationship habits are also factors that shape organizational life. Therefore, it can be concluded that individuals who do not feel alone in their personal social lives do not feel lonely in their professional lives either.

One of the main results of this study is that the employees included in the research do not feel lonely at their workplaces, a finding that could be assessed at the organizational level. In this framework, various organizational practices, such as improving the personnel's culture of team working, planning social activities in and outside the organization to enhance interactions among employees, restructuring formal and informal communication channels, employing experts

\section{References}

Allen, N. \& Meyer, J.P. (1990). The Measurement and Antecedents of Affective, Continuance and Normative Commitment to the Organization, Journal of Occupational Psychology, 63, 1-18.

Asher, S.R., Hymel, S. \& Renshaw, P.D. (1984). Loneliness in Children, Child Development, 55 (4), 1456-1464.

Asher, S.R. \& Paguette, J.A. (2003). Loneliness and Peer Relations in Childhood, Current Directions in Psychological Science, 12 (3), 75-78.

Atabek A., Coşar E. E. \& Şahingöz S. (2005). A Composite Leading Indicator for the Turkish Economic Activity, Central Bank of the Republic of Turkey, 13.

Bluedorn, A.C. (1982). The Theories of Turnover: Causes, Effects, and Meaning, Research in The Sociology of Organizations, 1, 75-128. to provide psychological / social support services, and forming a well-constructed organizational culture adopted by employees, are factors that may help employees to not feel lonely at work.

Particularly, to prevent employees from feeling lonely in the work environment, management should formulate policies to improve social relations. It is beneficial to organize training programs on subjects including conflict management, human relations, communication techniques, and team work. However, loneliness should be assessed at the individual level as loneliness at work may be affected by factors related to the employee's personal social life. The factors related to the employee's personal social life may naturally prevent organizations from developing precautions against loneliness at work.

The necessity to assess the phenomenon of loneliness at the individual level also constitutes the most important restriction of the study. Thus, conducting this research with different sample groups may change the findings obtained in this study. The next study will attempt to measure the identified discrepancy using a different sample group.

Booth, Richard, (1983). Toward an Understanding of Loneliness, National Association of Social Workers, Inc., 116-119.

Cacioppo, John T., Hawkley, L.C. \& Bernston, G.G. (2003). The Anatomy of Loneliness, Current Directions in Psychological Science, 12 (3), 71-74.

Cacioppo, John T. \& Patrick, William (2008). Loneliness: Human Nature and the Need for Social Connection, New York: W.W. Norton \& Co.

Cho, S., Johanson, M.M. \& Guchait, P. (2009). Employee Intention to Leave: A Comparison of Determinants of Intention to Leave Versus Intention to Stay, International Journal of Hospitality Management, 28, 374-381.

Çivitçi, N. \& Çivitçi, A. (2009). Self-Esteem As Mediator and Moderator of The Relationship Between Loneliness and Life Satisfaction in Adolescents, Personality and Individual Differences, 47, 954-958. 
Demir, A. (1989). UCLA Yalnızlık Ölçeğinin Geçerlik ve Güvenilirliği, Psikoloji Dergisi, 7 (23), 1418.

Dhar, R.L. \& Dhar, M. (2010). Job Stress, Coping Process and Intentions to Leave: A Study of Information Technology Professionals Working in India, The Social Science Journal, 47, 560-577.

Doğan, T., Çetin, B. \& Sungur, M. Z. (2009). İş Yaşamında Yalnızlık Ölçeği Türkçe Formunun Geçerlilik ve Güvenilirlik Çalışması, Anadolu Psikiyatri Dergisi, 10, 271-277.

Dunteman G. H. (1989). Principal Components Analysis, Sage Publications, London.

Erdil, O. \& Ertosun, Ö.G. (2011). The Relationship Between Social Climate and Loneliness in the Workplace and Effects on Employee Well-Being, Procedia Social and Behavirol Sciences, 24, 505-525.

Ertosun, Ö.G \&. Erdil, O. (2012). The Effects of Loneliness on Employees' Commitment and Intention to Leave, Procedia Social and Behavioral Sciences, 41, 469-476.

Ernst, J.M. \& Cacioppo, J.T. (1999). Lonely Hearts: Psychological Perspectives on Loneliness, Applied $\mathcal{E}$ Preventive Psychology, 8, 1-22.

Forbes, A. (1996). Loneliness, British Medical Journal, 313 (7053), 352-354.

Huang, T.C., Lawler, J. \& Lei, C.Y. (2007). The Effects of Quality of Work Life on Commitment and Turnover Intention, Social Behavior and Personality, 35 (6), 735-750.

Hwang, J.I. \& Chang, H. (2009). Work Climate Perception and Turnover Intention Among Korean Hospital Staff, International Nursing Review, 56, 7380.

Johnson, D.E. (1998). Applied Multivariate Methods for Data Analysis, International Thompson Publishing, London.

Jolliffe, I.T. (2002). Principal Component Analysis, II. Edition, Springer-Verlag, New York.

Karadağ, M., Teke, A. \& Demir, C. (2011). Gata'da Görevli Akademik Yönetici Personelin Örgütsel Bağlılık ve Örgütten Ayrılma Düşünceleri Üzerine Bir İnceleme, Gülhane Tip Dergisi, 53, 162-169.

Kraus, L.A., Davis, M.H., Bazzini, D., Church, M. \& Kirchman, C.M. (1993). Personal and Social Influences on Loneliness: The Mediating Effect of
Social Provisions, Social Psychology Quarterly, 56 (1), 37-53.

Labatmediene, L., Endriulaitiene, A. \& Gustainiene, L. (2007). Individual Correlates of Organizational Commitment and Intention to Leave the Organization, Baltic Journal of Management, 2 (2), 196-212.

Lasgaard, M. (2007). Reliability and Validity of the Danish Version of UCLA Loneliness Scale, Personality and Individual Differences, 42, 1359-1366.

Liu, L.J \& Guo, Q. (2007). Loneliness and Health Related Quality of the Life for the Empry Nest Elderly in the Rural Area of a Mountainous County in China, Quality of Life Research, 16 (8), 1275-1280.

Liu, B., Liu, J. \& Hu, J. (2010). Person Organization Fit, Job Satisfaction, and Turnover Intention: An Empirical Study in the Chinese Public Sector, Social Behavior and Personality, 38 (5), 615-626.

Loi, R., Hang-Yue, N. \& Foley, S. (2006). Linking Employees' Justice Perceptions to Organizational Commitment and Intention to Leave: The Mediating Role of Perceived Organizational Support, Journal of Occupational and Organizational Psychology, 79, 101120.

Lopata, H.Z. (1969). Loneliness Forms and Components, Social Problems, 17 (2), 248-262.

Mellor, D., Stokes, M., Firth, L., Hayashi, Y. \& Cummins, R. (2008). Need for Belonging, Relationship Satisfaction, Loneliness, and Life Satisfaction, Personality and Individual Differences, 45, 213-218.

Mobley, W.H., Horner, S.O. \& Hollingsworth, A.T. (1978). An Evaluation of Precursors of Hospital Employee Turnover, Journal of Applied Psychology, 63, 408-414.

Mobley, W.H. (1982a). Employee Turnover: Causes, Consequences, and Control, Addison-Wesley, Reading, MA.

Mobley, W.H. (1982b). Some Unanswered in Turnover and Withdrawal Research, Academy of Management Review, 7, 111-116.

Neto, F. (1992). Loneliness Among Portuguese Adolescents, Social Behavior and Personality: An International Journal, 20 (1), 15-22.

Nurmi, J. \& Katariina, S. (1997). Social Strategies and Loneliness: A Prospective Study, Personality and Individual Differences, 23 (2), 205-215. 
Özdevecioğlu, M. (2004). Algilanan Örgütsel Desteğin İşten Ayrılma Niyeti Üzerindeki Etkileri, Amme İdaresi Dergisi, 37 (4), 97-115.

Peplau, H.E. (1955). Loneliness, The American Journal of Nursing, 55 (12), 1476-1481.

Peplau, L.A. \& Perlman, D. (1984). "Loneliness Research: A Survey of Empirical Findings", In L.A. Peplau, S.E. Goldston (Eds.), Preventing the Harmful Consequences of Severe and Persistent Loneliness, 13-47, Rockville Maryland: National Inst. of Mental Health.

Pidd, V.D.K. \& Roche, A.M. (2009). The Impact of Work Stress and Job Satisfaction on Turnover Intention: A Study of Australian Specialist Alcohol and Other Drug Workers, Drugs: Education, Prevention and Policy, 16 (3), 217-231.

Plooy, J. \& Roodt, G. (2010). Work Engagement, Burnout and Related Constructs as Predictors of Turnover Intention, SA Journal of Industrial Psychology, 36 (1). 1-13.

Ponzetti, J.J. (1990). Loneliness Among College Students, Family Relations, 39 (3), 336-340.

Revenson T. (1981). Coping With Loneliness: The Impact of Casual Attributions, Personality and Social Psychology Bulletin, 7, 565-571.

Rosser, V.J. (2004). Faculty Members' Intention to Leave: A National Study On Their Worklife and Satisfaction, Research In Higher Education, 45 (3), 285309.
Russell, D.W. (1996). UCLA Loneliness Scale (Version 3): Reliability, Validity and Factor Structure, Journal of Personality Assessment, 66, 20-40.

Savikko, N., Routasalo, P., Tilvis, R.S., Strandberg, T.E. \& Pitlaka, K.H. (2005). Predictors and Subjective Causes of Loneliness in an Aged Population, Archives of Gerontology and Geriatrics, 41, 223-233.

Simon, M., Müller, B.H. \& Hasselborn, H.M. (2009). Leaving the Organization or the Profession-a Multilevel Analysis of Nurses' Intentions, Journal of Advanced Nursing, 66 (3), 616-626.

Tak, B. \& Çiftçioğlu, B.A. (2009). Mesleki Bağlı̆ık ile Çalışanların Örgütte Kalma Niyetleri Arasındaki İlişkiyi İncelemeye Yönelik Görgül Bir Çalışma, Ankara Üniversitesi Sosyal Bilimler Fakültesi Dergisi, 63 (4), 155-178.

Tsai, Y. \& Wu, S.W. (2010). The Relationship Between Organizational Citizenship Behavior, Job Satisfaction and Turnover Intention, Journal of Clinical Nursing, 19, 3564-3574.

Yılmaz, E. (2008). Organizational Commitment and Loneliness and Life Satisfaction Levels of School Principles, Social Behavior and Personality, 36 (8), 1085-1096.

Wright, S. L., Burt, C.D.B. \& Strongman, K.T. (2006). Loneliness in the Workplace: Construct Definition and Scale Development, New Zeland Journal of Psychology, 35 (2), 59-68. 